\title{
Synthesis of PEG-PLA Block Copolymer Nanospheres Containing Mixed Recombinant Proteins of Protective Antigen and Lethal Factor of Bacillus anthracis
}

\author{
Hossein Honari $^{*}$ iD , Mohammad Ebrahim Minaei ${ }^{1}$, Hassan Mirhaj ${ }^{1}$, Sayyed Masih Etemadaubi ${ }^{1}$ \\ ${ }^{1}$ Dept of Biology, Faculty of Basic Sciences, Imam Hossein Comprehension University, Tehran, Iran
}

\section{Article Info}

Article type:

Research article

\section{Article History:}

Received: 05 December 2020

Revised: 16 December 2020

Accepted: 01 September 2021

\section{* Correspondence to: \\ Hosein Honari}

Dept of Biology, Faculty of Basic Sciences, Imam Hossein Comprehension University, Tehran, Iran

Email: Honari.hosein@gmail.com

\section{A B S T R A C T}

Introduction: Anthrax is a zoonotic disease and vaccine production is one way to protect people against this bacterium. This study investigates the application of copolymer nanocapsule (PEG-PLA) systems with controlled release specificity for a recombinant protective antigen and lethal factor of Bacillus anthracis to provide a vaccine candidate.

Material \& Methods: In this experimental study, the dual solvent evaporation emulsion method was used to produce nanocapsules. Moreover, zeta potential and size of nanoparticles, loading efficiency of nanoparticles, recombinant protein release pattern, the probable effect of PLA-PEG nanoparticle production on the shelf life of recombinant proteins were investigated in this study. Mice were used as test and control samples for antibody production and immune response evaluation.

(Ethic code: 9727250)

Findings: The results of this study showed that mixed proteins (LFD1+PAD4) loaded on PEG-PLA block copolymer had an average size of $109 \mathrm{~nm}$, the zeta potential of $-27.7 \mathrm{mV}$, and $\mathrm{PDI}=0.394$. In this study, it was shown that the release of these antigens was carried out in two stages of rapid and slow release. The release of the proteins was estimated at about $20 \%$ on the first day and $78 \%$ on the 49th day. The titers of antibodies produced in the serum of the mouse groups against these antigens at defined intervals were significantly different from each other.

Discussion \& Conclusion: The results of this study suggest the application of PEG-PLA block copolymer nanocapsules containing mixed recombinant proteins of protective antigen and lethal factor of Bacillus anthracis. Due to less degradation and more protection of antigen activity in nanoparticles, compared to traditional methods, as well as fewer repeat injections, higher specificity, reduced side effects, lower cost, and slower release rate, the use of nanoparticles is a good option to replace traditional methods.

Keywords: Copolymer nanocapsule, Lethal factor, Protective antigen, Vaccine

\section{$>$ How to cite this paper}

Honari H, Minaei ME, Mirhaj H, Etemadaubi SM. Synthesis of PEG-PLA Block Copolymer Nanospheres Containing Mixed Recombinant Proteins of Protective Antigen and Lethal Factor of Bacillus anthracis. Journal of Ilam University of Medical Sciences. 2022;29(5): 89-101. 


\section{سنتز نانوسفر كويليمرى دوبلو كه PEG-PLA حاوى مخلوط يروتئينهاى نوتر كيب آنتىخن محافظت كننله و فاكتور كشنلهُ باسيلوس آنتراسيس}

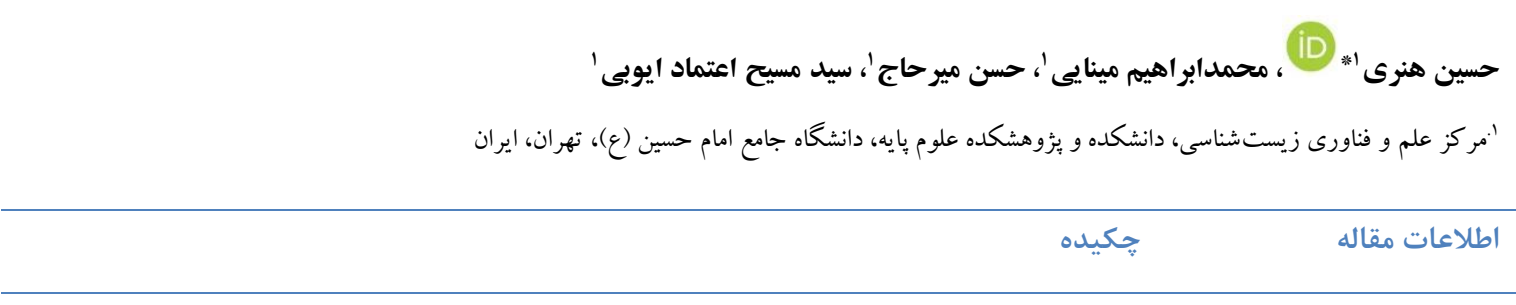

مقدمه: سياهزخم از بيمارىهاى مشترك انسان و دام است و توليد واكسن يكى از راههاى محافظت افراد در برابر اين

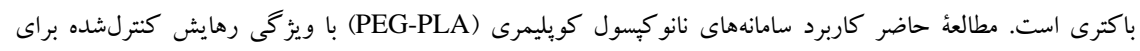

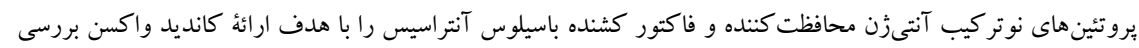

مى كند. مواد و روش ها: در اين مطالعة تجربى، براى توليد نانو كِيسولها از روش امولسيون دو كانهُ تبخير حلال استفاده شد و

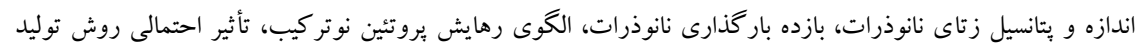

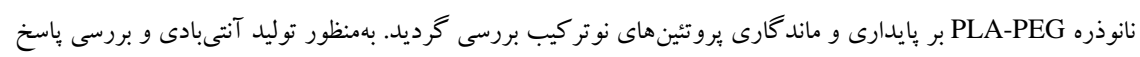

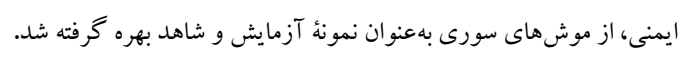

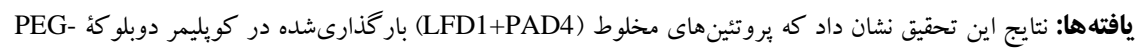

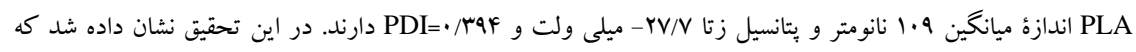

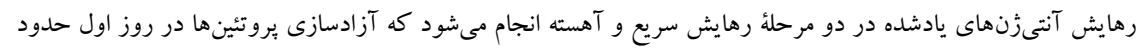

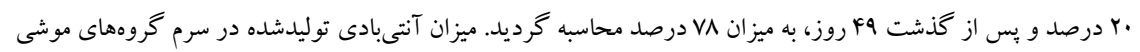

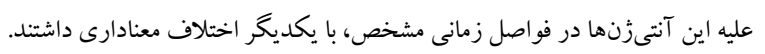

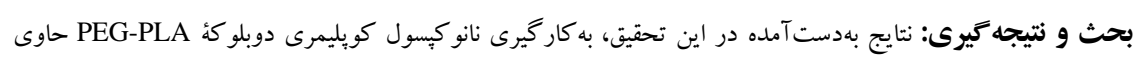

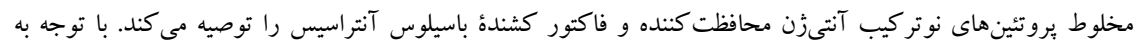

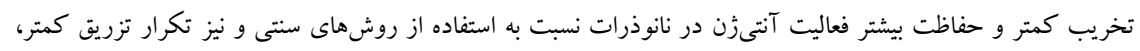

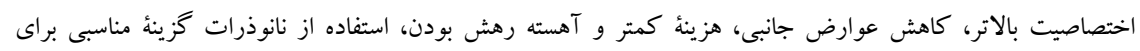
جايخزين شدن با روشهاى سنتى است.
نوع مقاله: يُروهشى

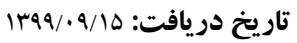
تاريخ داورى:

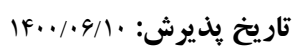

$$
\text { حويسنده مسئول: }
$$

مركز علم و فناورى زيستشناسى، دانشكده و يزٔوهشكده علوم وِايه، دانشگاه جامع امام حسين (ع)، تهران، ايران Email:

Honari.hosein@gmail.com

\section{وازههاى كليدى: آنتىرن محافظت كنده، فاكتور كشنده، نانو كِّول كويليمرى، واكسن}

> استناد: هنرى، حسين؛ مينايى، محمد ابراهيم؛ ميرحاج، حسن؛ اعتماد ايوبى، سيد مسيح. سنتز نانوسفر كويليمرى دوبلو كة

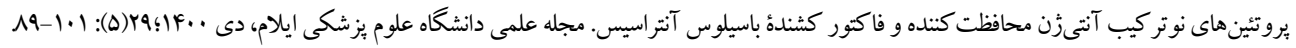


pXO1 قرار گرفته است و ييشتر به pBA1 معروف بود. ساختار سهبعدى آنتىزن حفاظتى شناسايىشده است. ساختار كريستالى آن نشان ميدهد كه اين مولكول به جهار دومين مجزا از نظر عملكردى تقسيمبندى مىشود

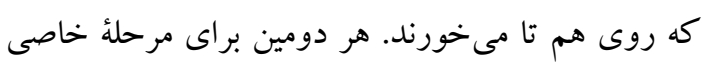
از ايجاد سميت ضرورى است (ه). واكسيناسيون مؤثرترين روش بيشخيرى از بيمارى سياهزخم محسوب مىشود كه مىتواند جان هزاران نفر را نجات بخشد. عامل اين بيمارى شامل سه جزء مهم يعنى اسبور، باسيل و سم است كه حذف هريكك از اين موارد

حفاظت حداقل را عليه سياهزخم ايجاد مى كند (4). سويههاى بيمارىزاى باسيلوس آنتراسيس واجد دو يلاسميد بزرگك هستند: پيلاسميد تو كسين pXO1 و يلاسميد كِسول pXO2 سويههايى كه تنها واجد يكى از اينها باشند، غير بيمارىزا هستند. اولين واكسن كه ياستور در سال |MM| توليد كرد، يك سوية تخفيف حدت يافته بود (pXO1-/pXO2+) كه كֶسول داشت؛ اما تو كسين توليد نمى كرد. اين سويه سطح بسيار بايين ترى از ايمنى را در مقايسه با سويههاى واكسن توليد كندهُ تو كسين ايجاد مىنمود. واكسنى كه ياستور تهيه كرده بود، •ه سال بهطور وسيع در ارويا و آمريكا، براى واكسينه نمودن گاو و گوسفندها به كاربرده شد (V). واكسنهاى تأييدشدة AVA (استفادهشده در آمريكا) و AVP (استفادهشده در انخليس) براى جلو گيرى از مرگكومير ناشى از سياهزخم كاربرد دارند. آنتىزن حفاظتى (PA) جزء اصلى اين واكسنها است كه در ساختار توكسين كشنده و ادم مشترك است و اين تو كسينها نقش اصلى را در بيمارىزايى باكترى دارند.AVP در مقايسه با AVA، حاوى سطوح يايينترى از PA و غلظتهاى بالاترى از آنتىزنهاى ديخر سياهزخم مانند فاكتور كشنده (LF)، فاكتور ادم (EF) و برخى از يروتئين هاى سطحى است و درنتيجه ممكن است از نظر ايجاد مصونيت به بيمارى، از AVA اندكى بهتر

\section{مقدمه}

بيمارى سياهزخم در انسان، درنتيجهُ تماس مستقيم با حيوانات بيمار و يا فراوردههاى حيوانات مانند بوست، مو و يشم ايجاد مىشود؛؛ بنابراين داميزشكان، دامداران،

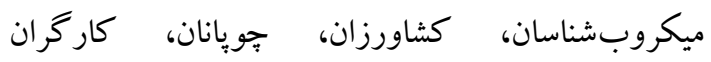
كشتار كاهها و كارگران مشغولبه كار در صنايع يوست و يشم، بيشتر در معرض ابتلا به اين بيمارى هستند. سه راه بروز آلودگى در انسان بهصورت يوستى، تنفسى و

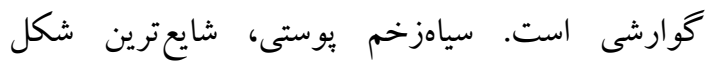
سياهزخم در انسان است كه درنهايت، موجب ايجاد يكك

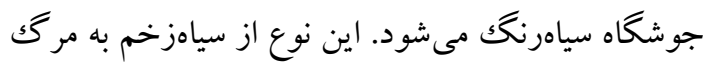
در • r درصد موارد منجر مى گردد. سياهزخم تنفسى كه درنتيجه تنفس اسبورباكترى رخ مىدهد، كشندهترين شكل بيمارى محسوب مىشود و موجب مرگك بيمار در

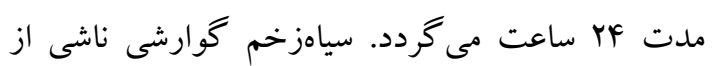
مصرف غذاى آلوده به اسبور و نادرترين شكل بيمارى در انسان است. تقريباً هه درصد از موارد ابتلا به سياهزخم در اله انسان، از نوع جلدى و ينج درصد از موارد، به شكل تنفسى است (Y) (1). باكترى باسيلوس آنتراسيس سه آنتىزن شامل آنتىزن كڤيسولى، آنتىزن سوماتيك و كميلكس سمى دارد (r). كميلكس سمى از سه جزء جدا كانه تشكيلشده است كه مسئول بيشتر نشانهاى بالينى براى سياهزخم است. اين سم شامل آنتىزن حفاظتى (rی كيلودالتون)، عامل كشنده ( •9 كيلودالتون) و عامل آماس يا ادم (19 كيلودالتون) است كه بهترتيب توسط زنهاى lef ،pag و cya موجود روى يلاسميد pXO1 باكترى كد مىشود. زن atXA بهعنوان فعال كنندهُ سم سياهزخم معروف است كه تنظيم كنندهُ رونويسى زنهاى كد كنندهُ سه سم يروتئينى است (F). وجود پِاسميد و زن تنظيمى atxA كه روى يلاسميد قرار گرفته، براى بيمارىزايى ضرورى است. آنتىزن حفاظتى به علت نقشى كه در فراخوانى پياسخ ايمنى حفاظتى عليه سياهزخم دارد، به اين نام خواندهشده است. زن كدكننده PA در لو كوس pag روى يلاسميد 
تحقيقات زيستشناسى دانشكاه جامع امام حسين(ع) تهيه و يروتئين هاى مربوط بيان و تخليص گرديد. براى توليد

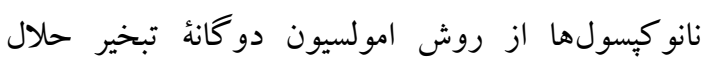
استفاده شد. در اين روش، محلول بافرى به فاز آلى شامل روش

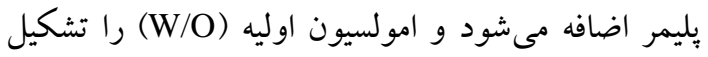
مىدهد. اين امولسيون بهآرامى و در حين هم زدن، به حجم بزرگى از آب كه شامل امولسيفاير است است

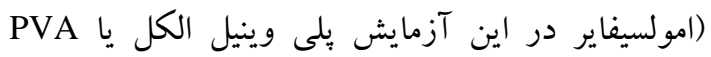

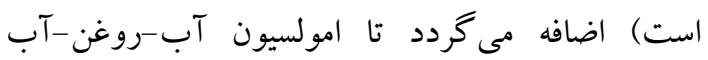

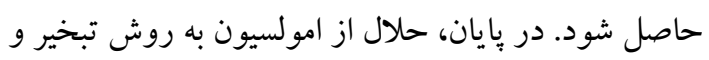
استخر اج حلال جدا مى گردد (r) (I).

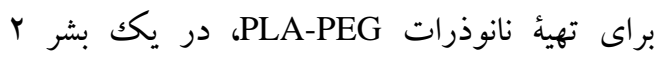

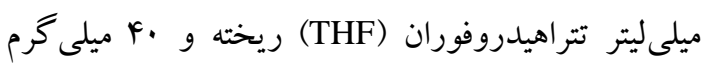
يليمر PLA-PEG اضافه و سيس حدود r ساعت اجازه داده شد تا يليمر روى همزن مغناطيسى بهخوبى حل شود.

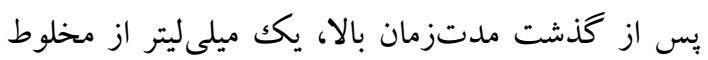

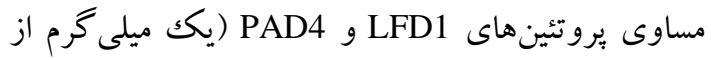
هر بروتئين) بهصورت قطرهقطره به محلول يليمرى در

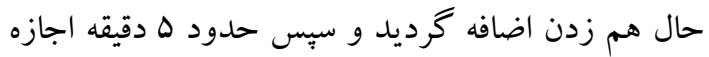
داده شد. بس از اين مرحله، امولسيون تهيهشده با قدرت

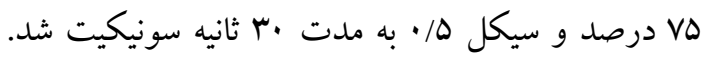

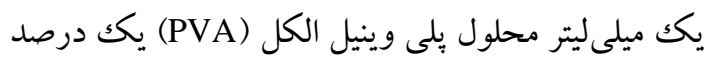

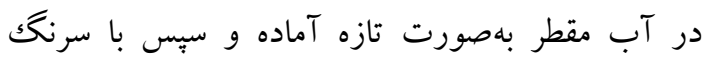

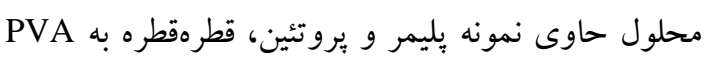

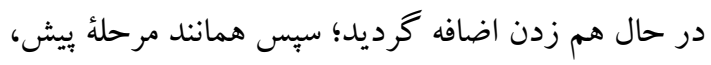

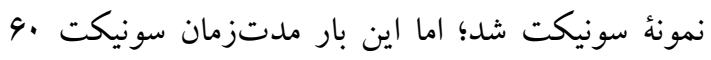

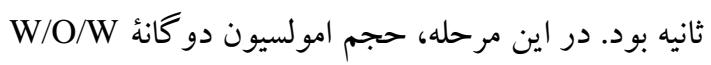

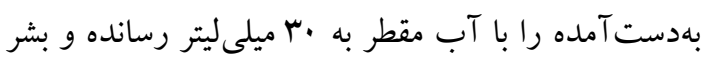

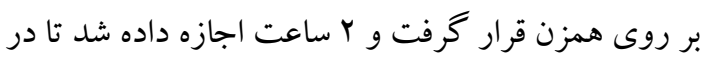

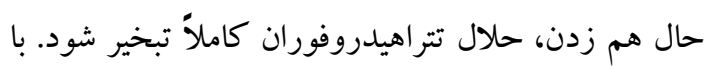
كذشت زمان لازم براى تبخير حلال و سخت شدن ذال ذرات موجود در محلول، جمع آورى ذرات آنها انجام گرفت.

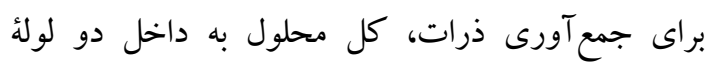

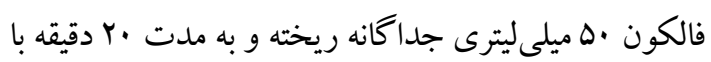

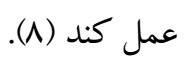

واكسنهاى مبتنى بر PA نوتركيب (rPA) يكى از كزينهاى جايكزين براى واكسنهاى AVA و AVP هستند. اين واكسنهاى نوتر كيب با سرعت بيشترى سبب مصونيت

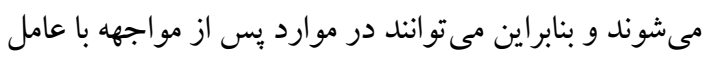

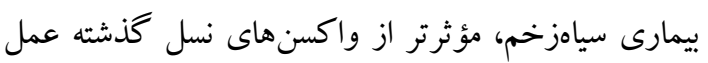
كند. از سويى، واكسنهاى نوتركيب از نظر فرمولاسيون، همخنى بالاترى دارند و ايمنى و مصونيتزايى اين واكسنها

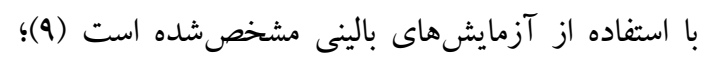

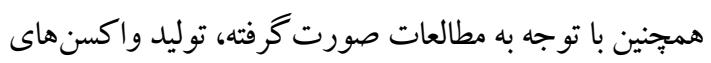
نوتر كيب حاوى PA و فاكتور كشنده مىتواند اثر كذارى بيشترى براى فعالسازى دستخاه ايمنى داشته باشد؛ درنتيجه، نسل هاى جديد واكسن بهسوى توليد واكسنهاى كايمر بين آنتىزن حفاظتى و فاكتور سم است (•(1). تجويز بهصورت داخل جلدى، جزو روشهاى موفقيت آميز براى

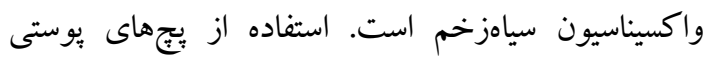
حاوى rPA و جايغزينى آن زيريوست، موجب القاى سطح

جشمخيرى از آنتىبادى در حيوانات الكو شده است (11).

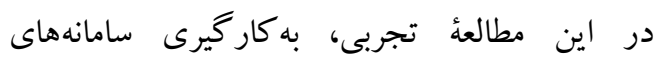

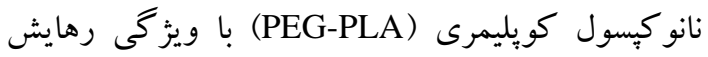
كنترلشده براى يروتئينهاى نوتركيب آنتىزن

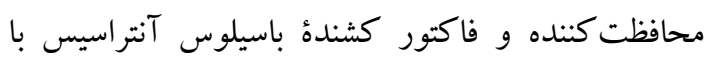
هدف ارائٔ كانديد واكسن بررسىشده است. استفاده از

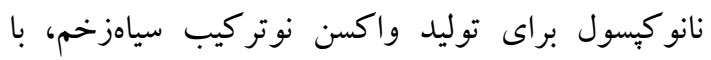
توجه به ويز گىهاى نانوذرات در رهايش و حفاظت بيشتر

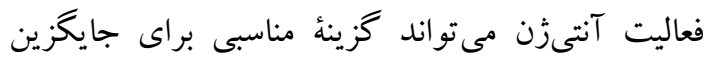
شدن با روش هاى سنتى باشد.

\section{مواد و روش ها}

تهيئ نانوذرات حاوى بروتئين هاى مخلوط LFD1 و

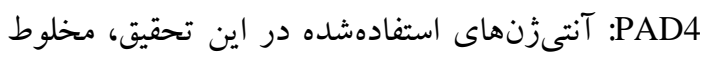
بروتئين هاى نوتر كيب LFD1 (دامنٔ الفاكتور كشنده) و PAD4 باكترىهاى داراى اين دو زن بهصورت جداكانه، از مركز 
حاوى r ميلى گرم بروتئن در حجم . PLA-PEG ميكروليتر محلول PBS درون ميكروتيوب r ميلىليترى ريخته و با هم زدن ير اكنده شد. ميكروتيوب درون شيكر ميكر

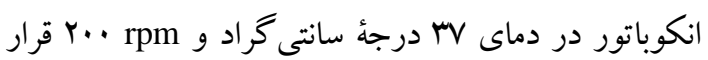
كرفت و در فواصل زمانى منظم، نمونهبردارى از محلول

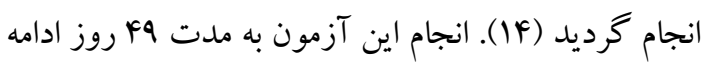
داشت؛ سبس با استفاده از روش بروتئينسنجى برادفورد با سه بار تكرار، غلظت يروتئين موجود در نمونه تعيين شد. درنهايت، منحنى درصد تجمعى يروتئين رهاشده از نانوذرات در مدتزمانهاى تعيينشده ترسيم گرديد. بررسى پايدارى و ماند كارى بروتئين در طول تهيئ نانوذرات: براى مشخص كردن تأثير احتمالى روش توليد نانوذره حجم مشخصى از محلول حاوى نانوذره يس از توليد به يكك لوله فالكون ها ميلى ليترى منتقل و سيس سانتريفيوز

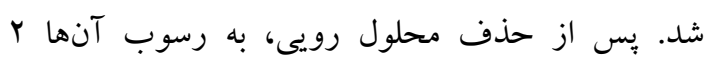
ميلىليتر بافر رهايش نانوذره (محلول حاوى SDS 5\% و (NaOH 0.1M اضافه گرديد (ها)؛ سيس نمونهُ نانوذرات در مدتزمان 19 ساعت در محلول رهايش سريع روى شيكر بهآرامى شك ش شدند. درنهايت، نمونهُ جمع آورىشده از تخريب كامل نانوذرات به همراه حجم مشخص : يروتئين نوتركيب، در زل زل

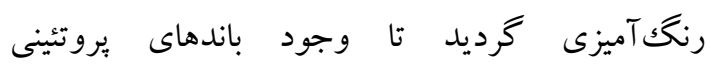
رهايششده از نانوذرات مشخص شود. تزريق زيريوستى بيروتئينهاى مخلوط (LFD1 و PAD4) به كروههاى موشى: بهمنظور توليد آنتىبادى و بررسى

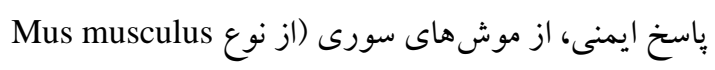

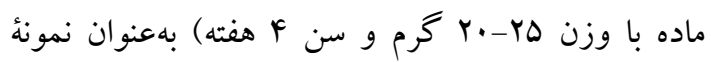
آزمايش و شاهد استفاده شد. براى انجام ايمنىزايى، مخلوط بروتئينهاى نوتر كيب PAD4+LFD1 (به نسبت مساوى) كه هر دو غير بار گذارىشده هستند، بهطور جداكانه طى جهار نوبت به گروه آزمايش بهترتيب در روز اول، روز جهاردهم، روز بيستوهشتم و روز

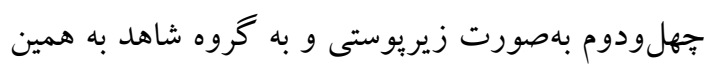

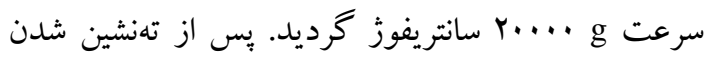

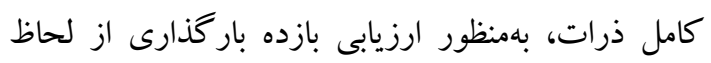

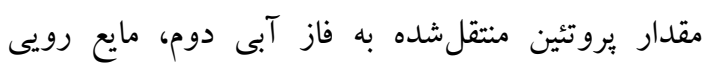
جمع آورى و بررسى شد؛ سيس رسوب دو بار و هر بار با ها ميلىليتر آب مقطر دو بار تقطيرشده شستشو داده و با

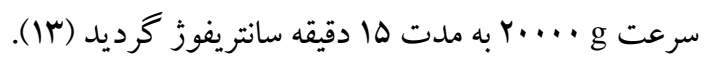
بررسى ويز گیىهاى ظاهرى نانوذرات: براى بررسى اندازءٔ

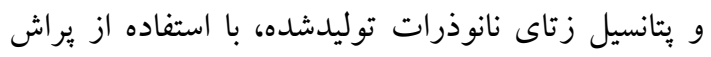
نور بويا از دستخاه DLSD مدل Malvern ساخت كشور انخلستان) استفاده شد. براى بررسى ويثز گیىهاى ظاهرى نانوذرات، از ميكروسكوبٍ الكترونى روبشى (SEM) (مدل EM3200 ساخت شركت KYKY ساخت كشور

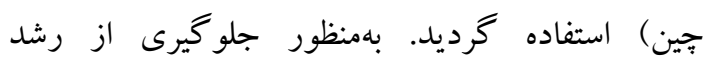
نانوذرات، نمونههاى تازه تهيهشده روى يكك سطح شيشهاى قرار كرفتند. بس از خشك شدن كامل، نمونه بهوسيلة يككلائُ ناز كك طلا با روش P.V.D يوشش داده شد. براى انجام لايهنشانى طلا از دستخاه Sputter coater (مدل

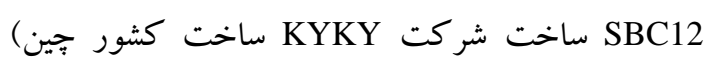
استفاده گرديد. درنهايت، يس از لايهنشانى، نمونهُ نانوذرات توسط ميكروسكوب ارزيابى شدند. بررسى بازده بار گذارى نانوذرات: بهمنظور بررسى بازده باركذارى نانوذرات، يس از تهيه نانوذرات و انجام سانتريفيوز، · · ميلى گرم از نانوذرات در يك ميلى ليتر سود يك مولار مخلوط و بهآرامى براى جند دقيقه، ورتكس و يروتئين در محلول PBS از نانوذرات خارج مى شود؛ سيس محلول سانتريفيوز و سوبٍ بهدست آمده براى مشخص شدن ميزان يروتئين آناليز مى گردد. بازده بار گذارى با استفاده از فرمول زير محاسبه مىشود (سا):

$$
\mathrm{EE}=\frac{m}{m_{0}} \times 100 \%
$$

$$
\text { m0 }
$$

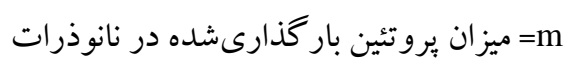
بررسى برونتن رهايش آنتىزن از نانوذرات: براى بررسى بـى بردي

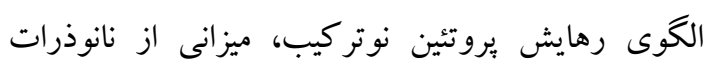


نانوذرات بدون بروتئين و PBS استفاده گرديد.

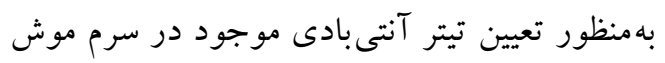

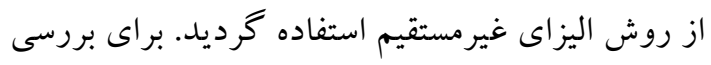

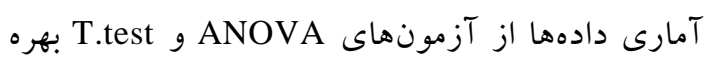

كرفته شد. اين آزمون براى مقايسٔ ميانگين تيتر آنداى

آنتىبادى نمونه ها انجام گرديد.
ترتيب PBS تزريق گرديد (جدول شماره ()؛ همجنين

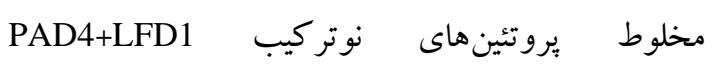

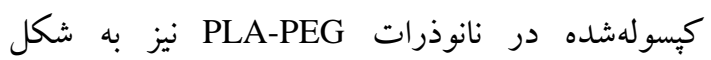

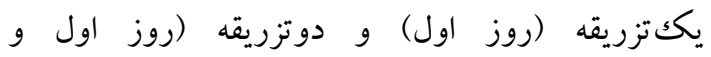

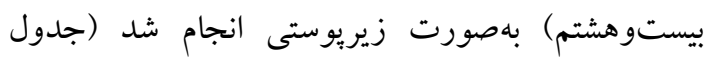

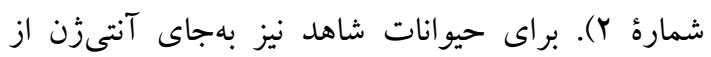

جدول 1. گروهها، زمان و مقادير برو تئينى غير بار گذارىشده تزريقى در مر احل ايمنسازى

\begin{tabular}{|c|c|c|c|c|c|c|c|}
\hline \multirow[t]{2}{*}{ روش تزريق } & موشها در & 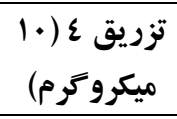 & 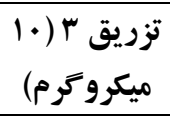 & 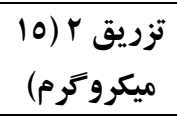 & 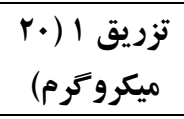 & \multirow[t]{2}{*}{ يروتئين تزريقى } & \multirow[t]{2}{*}{ رديف } \\
\hline & هر تروه & روز & روز ب^r & روز عا & روز اول & & \\
\hline \multirow[t]{2}{*}{ زيريوستى } & \multirow{2}{*}{ لهر عرو در هر } & \multirow[t]{2}{*}{+} & + & + & \multirow[t]{2}{*}{+} & يرو تئين مخلوط & 1 \\
\hline & & & + & + & & PBS & r \\
\hline
\end{tabular}

جدول r. گروهها، زمان و مقادير بروتئينى باركذارى شدهُ تزريقى در مراحل ايمن سازى

\begin{tabular}{|c|c|c|c|c|c|}
\hline \multirow{2}{*}{ روش تزريق } & \multirow{2}{*}{ تعداد موشها هر گروه } & تزريق † (·r ميكرو كرم) & تزريق ا (·r ميكروكرم) & \multirow{2}{*}{ يروتئين تزريقى } & \multirow{2}{*}{ رديف } \\
\hline & & روز ^r & روز اول & & \\
\hline \multirow{3}{*}{ زيريوستى } & & - & + & 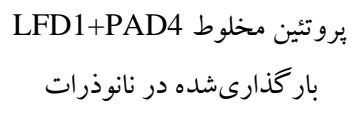 & 1 \\
\hline & كروه & + & + & $\begin{array}{l}\text { بروتئين مخلوط LFD1+PAD4 باركذارى شده در نانوذرات } \\
\text { بات }\end{array}$ & r \\
\hline & & + & + & PLA-PEG نانوذرات & $r$ \\
\hline
\end{tabular}

نتايج بررسى برونتن رهايش آنتىزن از نانوذرات: براى بررسى برونتن رهايش آنتىزن از نانوذرات

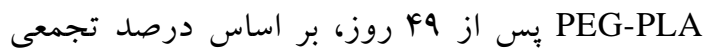

$$
\text { جدول "r. بررسى مقدار بهيئة ظرفيت بار خيرى با تغيير غلظت }
$$

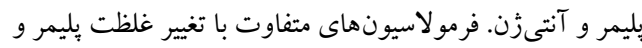

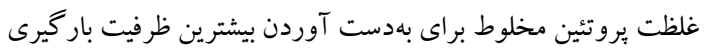

\begin{tabular}{|c|c|c|}
\hline \multicolumn{3}{|c|}{ نانوذرات تهيه شد. } \\
\hline $\begin{array}{c}\text { درصد ظبرفيت } \\
\text { LFD1+PAD4 } \\
\text { LFDA }\end{array}$ & غخلظت يروتئين & غلظت يُليمر \\
\hline$F \varphi / F$ & $r$ & $r$ \\
\hline$r \Delta / f$ & $r$ & r \\
\hline \&l & $r$ & 9 \\
\hline$\mu$ & r & $\wedge$ \\
\hline Fr & 1 & r \\
\hline
\end{tabular}

يافته ها

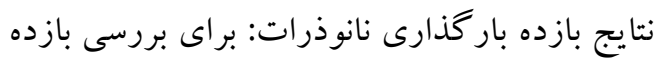

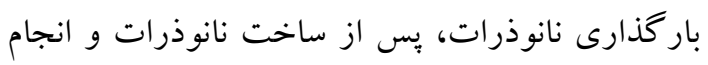

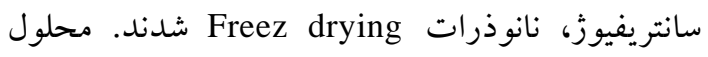
رويى جمع آورى و بروتئينسنى انجام و بر اساس فرمول بخش روش ها ظرفيت باركيرى نانوذرات

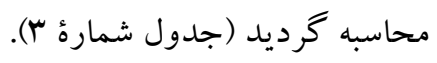
بر اساس نتايج جدول شمارة سا، بهترين شرايط براى

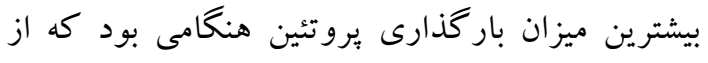

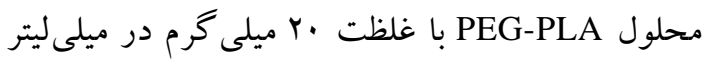

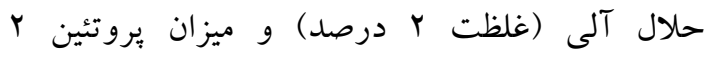

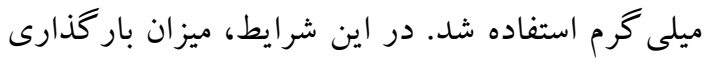

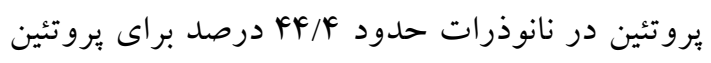
مخلوط محاسبه گرديد. 


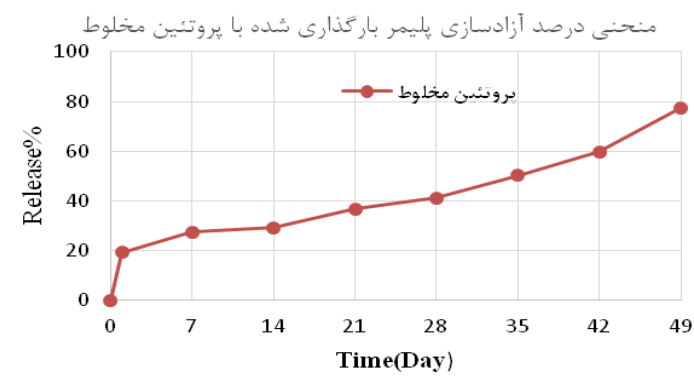

شكل ا. نتايج درصد تجمعى رهايش يروتئين نوتر كيب مخلوط از

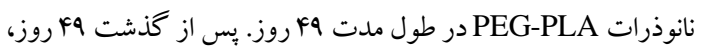

درصد رهايش يروتئين هاى مخلوط نوتر كيب PAD4+LFD1

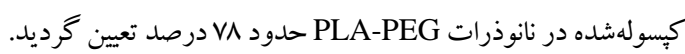

رهايش يروتئين در نمودار نمايش داده شد. همانطور كه در شكل شمارهٔ ا مشاهده مى شود، يس از اين مدتزمان، در حدود VA درصد رهايش از نانوذرات PEG-PLA نتايج بررسى ويز گى هاى ظاهرى نانوذرات: در بررسى اندازه و يتانسيل زتاى نانوذرات با استفاده از يراش نور بويا، نتايج نشاندهندهُ اين بود كه از نظر يتانسيل زتا و PDI نانوذرات در محدوده مناسبى قرار داشتند (جدول شماره: F).

جدول ع. بررسى ويز گى هاى فيزيكوشيميايى نانوذرات با استفاده از يراش نور يويا. با تغيير در مؤلفههاى مؤثر در فرايند ساخت نانوذرات، درنهايت

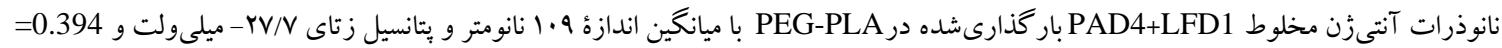
DPI

\begin{tabular}{|c|c|c|c|}
\hline PDI & اندازه (نانومتر) & يتانسيل زتا (ميلى ولت) & \\
\hline$\cdot / r r v$ & $I r / M$ & $-r Y / I$ & نمونة كنترل \\
\hline$\cdot /$ raf & 1.9 & $-Y V / V$ & $\begin{array}{r}\text { PAD4 و انوذرات حاوى مخلوط يروتئينهاى } \\
\text { LFD1 }\end{array}$ \\
\hline
\end{tabular}

در طول تهية نانوذرات و در شرايط خنثى، از طريق الكوى

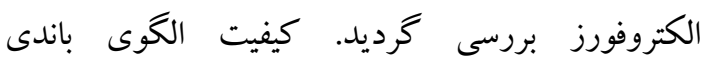
يروتئينهاى LFD1 و PAD4 بيش از باركذارى در نانوذرات PEG-PLA و يس از رهايش از آنها تغيير

$$
\text { مشخصى نداشت (شكل شمارهءf). }
$$

ارزيابى تيتر IgG در سرم موشهاى ايمنشده: بهمنظور ارزيابى تيتر آنتىبادى توليدشده از تزريق يرو تئين هاى مخلوط ( LFD1 و PAD4) به سه شكل
در بررسى ويزگى هاى ظاهرى نانوذرات توسط ميكروسكوب الكترونى، تصاوير ميكروسكوبِ الكترونى كروى و صاف بودن سطح ذرات حاصل از فرايند توليد نانوذرات در شرايط بهينه را مطلوب نشان داد. شكل شمارة r تصوير ميكروسكوبٍ الكترونى از نانوذرات تهيهشده است كه كروى و تا حد بسيارى حائز شر ايط ايدئال هستند.

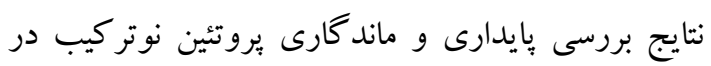
طول تهيةٌ نانوذرات: بايدارى و ماند گارى بروتئين نوتر كيب
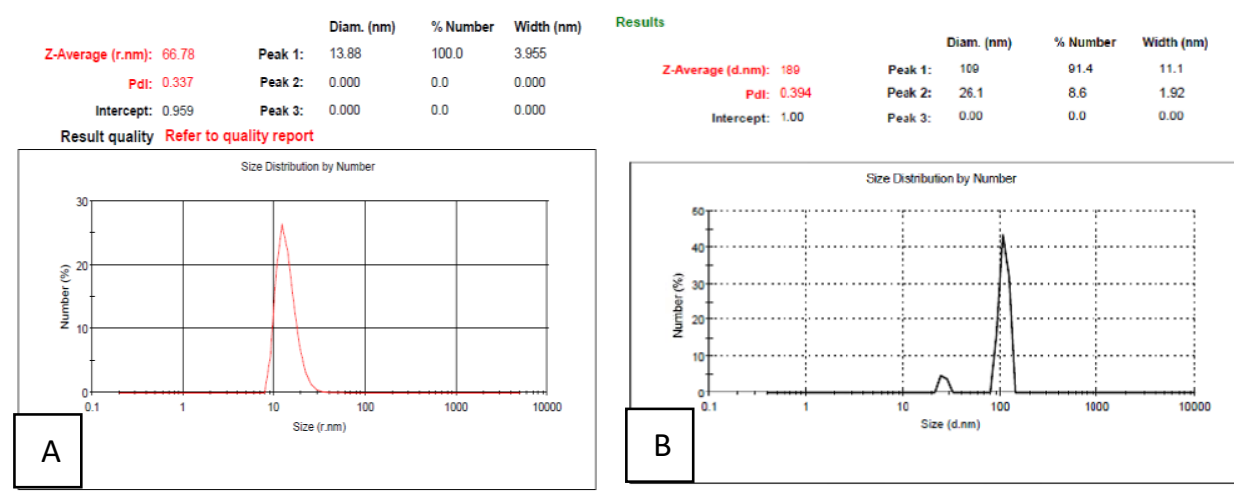

شكل r. نمودار بررسى بازه توزيع اندازه نانوذرات PEG-PLA حاوى بروتئين مخلوط A) PAD4+LFD1) و بدون بروتئين (B) در شرايط

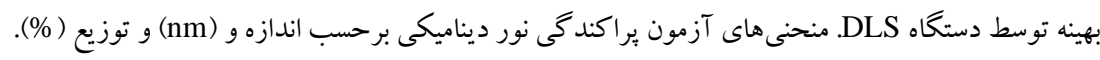


شد كه نتايج در شكلهاى شمارة ه، 9 و V مشاهده

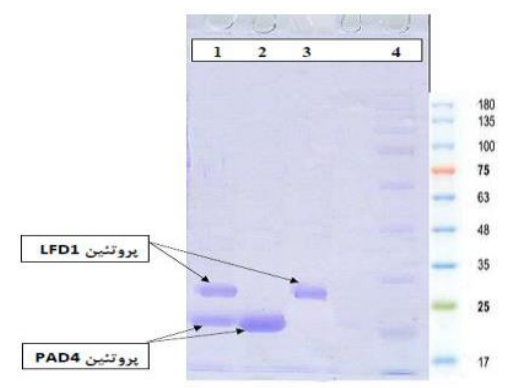

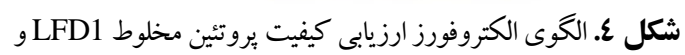

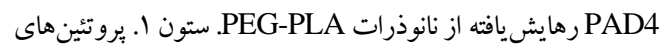

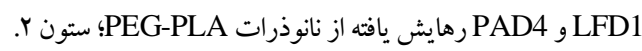

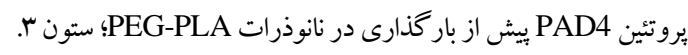

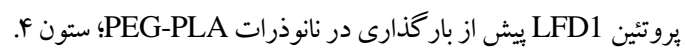

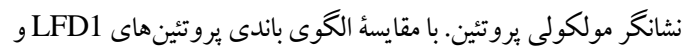

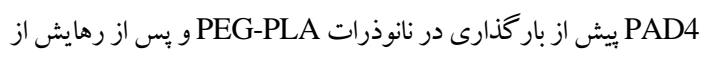

آنها، تغييرى در كيفيت آن ايجاد نشده است.

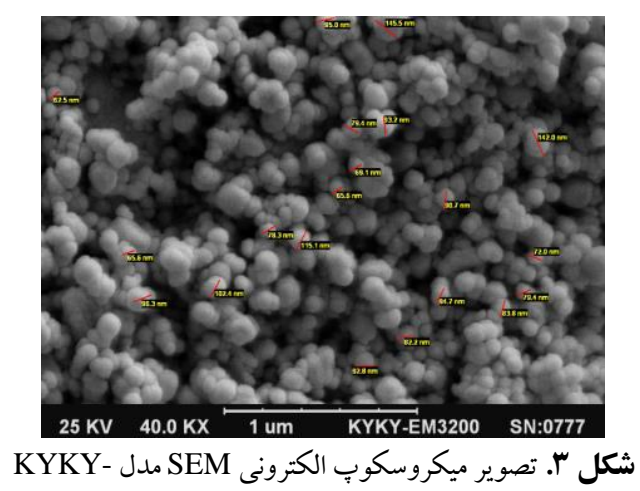

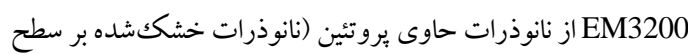

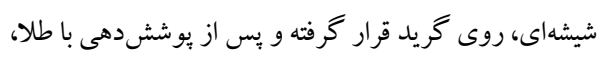

$$
\text { تصويربردارى شد). }
$$

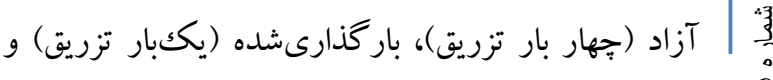

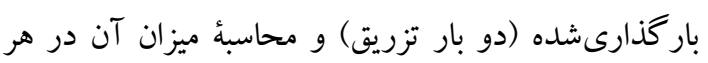

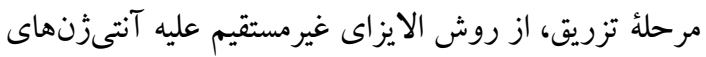

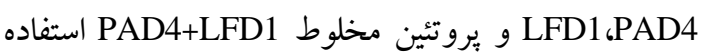
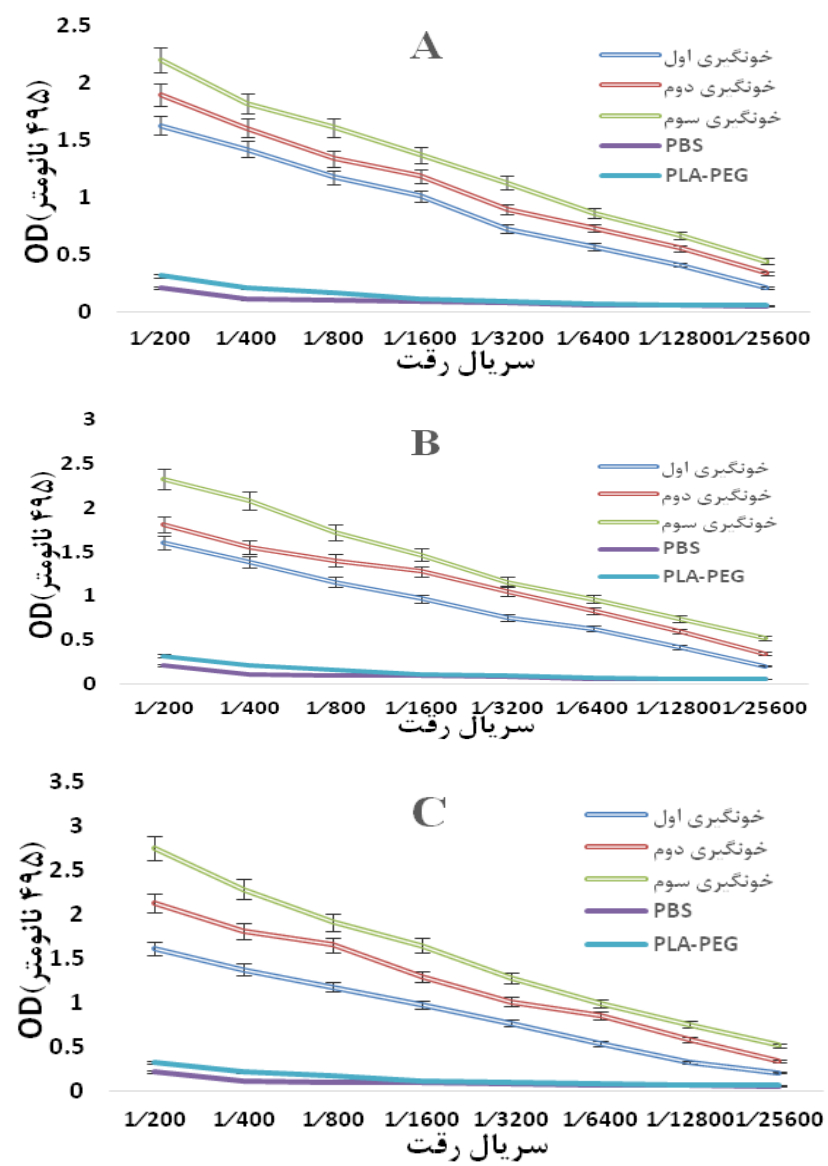

شكل ه. منحنى اليزاى توليد آنتىبادى IgG •اروز بِ از هر بار تجويز تزريقى يروتئين مخلوط LFD1 و PAD4 به سه صورت آزاد (A)،

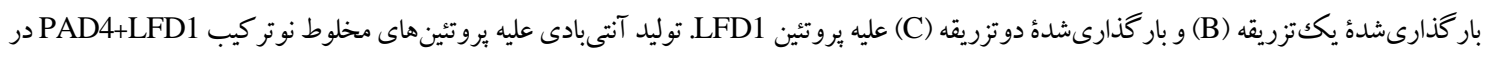

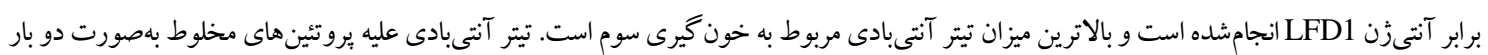

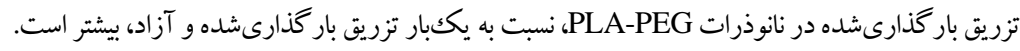



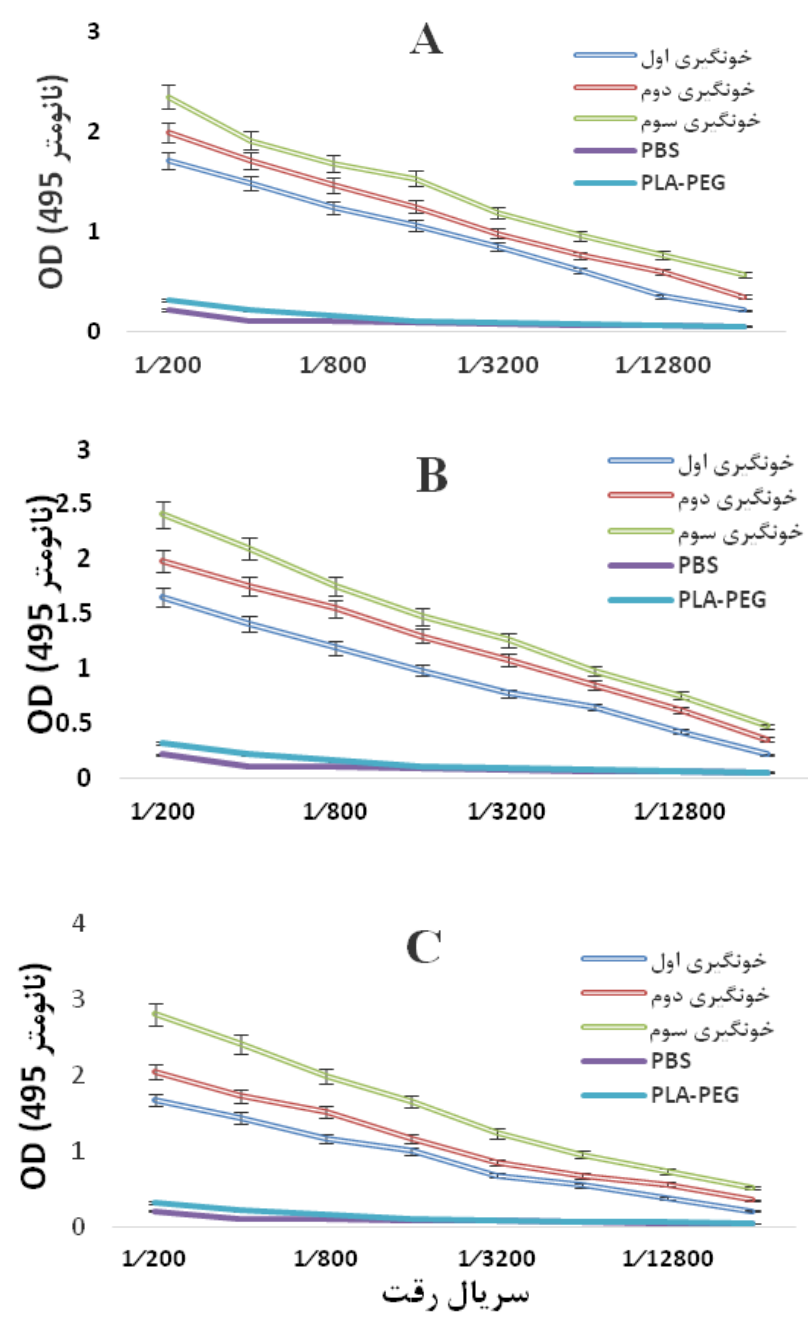

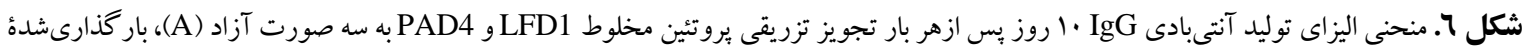

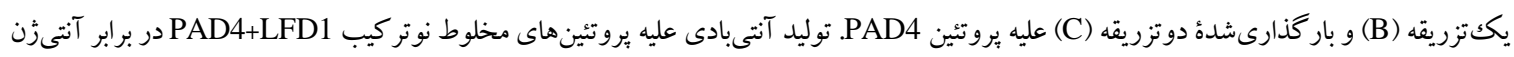

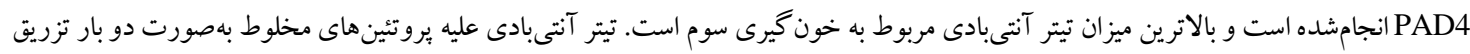

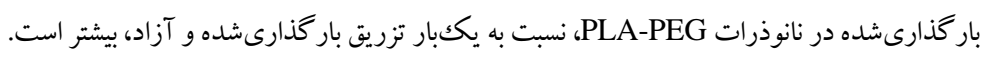

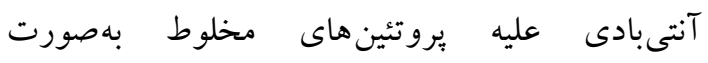

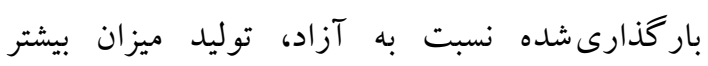

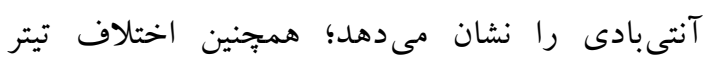

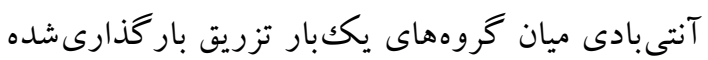

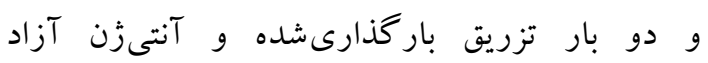
نشاندهنده آن است كه بيشترين تيتر آنتىبادى، مربوط ورد به دو بار تزريق باركذارىشده است. نتايج اليزا

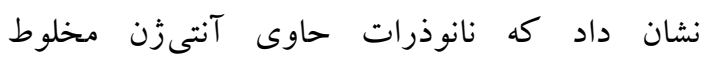
PAD4+LFD1

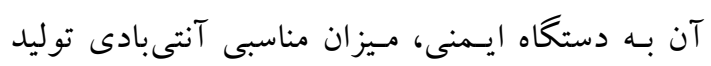

مىشود. نتايج نشان داد كه بالاترين ميزان تيتر آنتىبادى

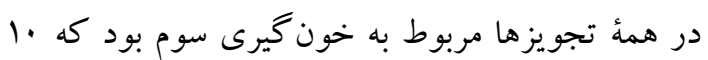
روز پِ از آخرين تزريق، خون كيرى از موشها

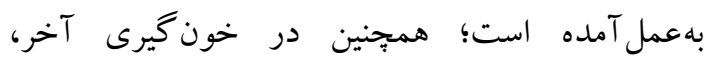

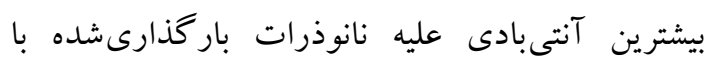
آنتىزن مخلوط PAD4+LFD1 اندازه گيرى شد. افزايش تيتر آنتىبادى در گروههائى كه نانوط ذانورات

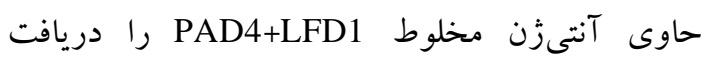
كردهاند، نشان مى دهد كه نانوذرات توانستهاند بهعنوان ادجوانت عمل كنند و با رهايش مناسب و طولانى مدت فردات آنتىزن، آنتىبادى بيشترى را توليد نمايند. تيتر 

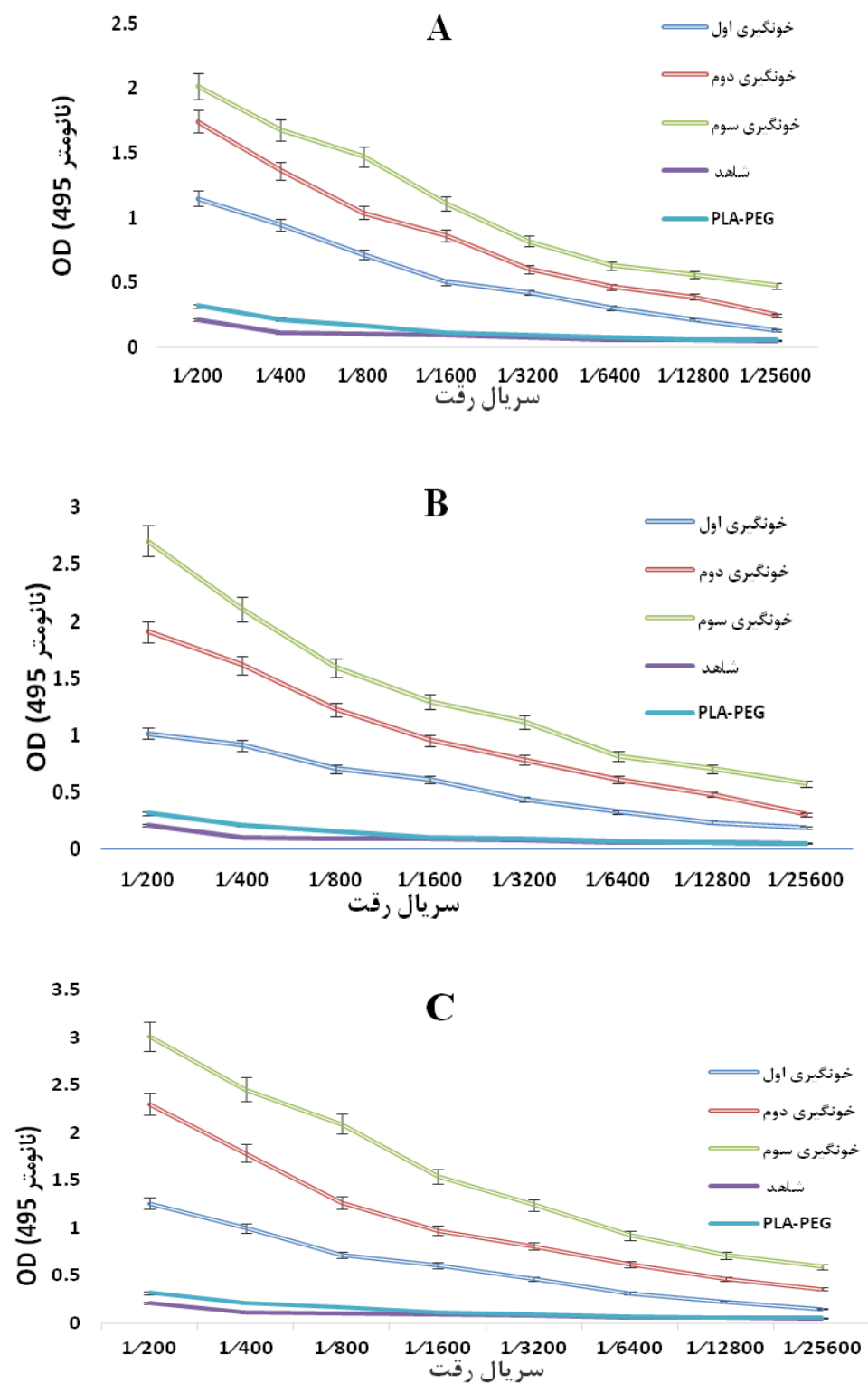

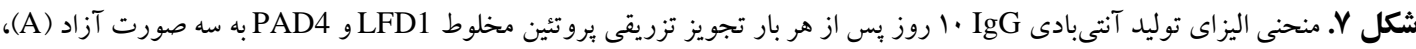

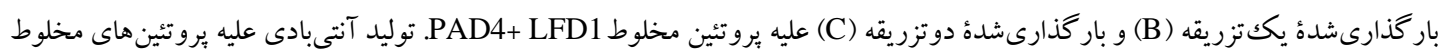

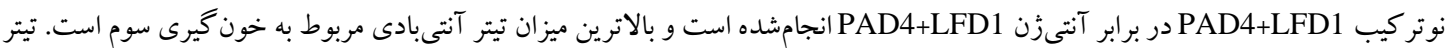

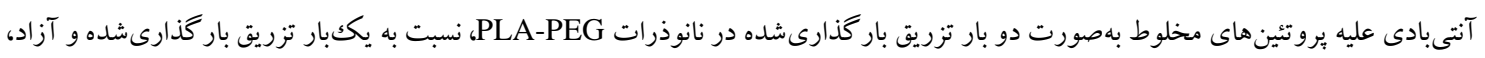

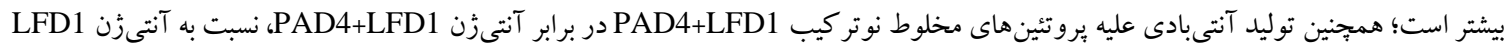
P (شكل شمارة ه) و آنتىرن PAD4 (شكل شمارة و) بيشتر بود.

ايفا مى كند. امروزه، تلاشهاى فراوانى براى بهينه كردن بحث و نتيجه كيرى

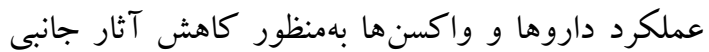
در جند سال اخير، به استفاده از سامانههاى كنترلى آن انجام مىشود. نانوذرات وسيلة مناسبى براى تحويل انتقال دارو و واكسن توجه شده است. كاربرد اين داروهايى با وزن مولكولى كم و نيز ماكرومولكولهاى سامانها بيانكر اين نكته مهم است كه سرنوشت و

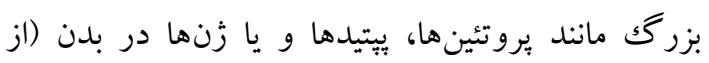
عملكرد دارو در بدن، تنها به خواص دارو بستگى ندارد، راههاى تجويزى مختلف) هستند (IV، 19). از نانوذرات بلكه رهايش كنترلشده آن نيز نقش مهمى در اين زمينه 
هيدروفيل بهويزه بروتئينها و كبسوله شدن بايين داروهاى قطبى تا حدودى محدود مىشود (YY). ماند كارى اندك سامانههاى همويليمرى PLA در خون، به علت تشخيص و به

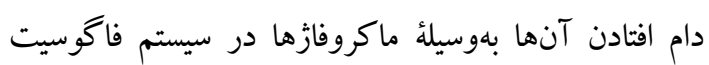

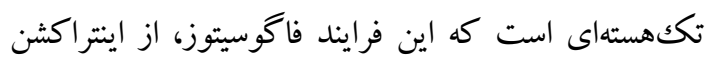
نانوذرات با بعضى از يروتئينهاى خون طى فر فرايند

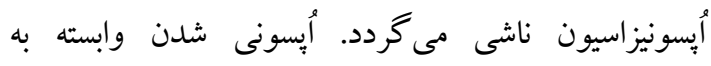

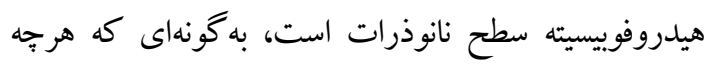

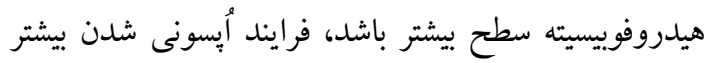

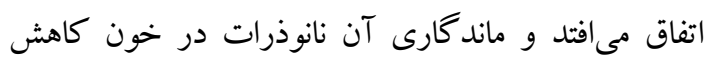
مىيابد (Yr). براى رفع اين معايب، از يلىاتيلن كليكول

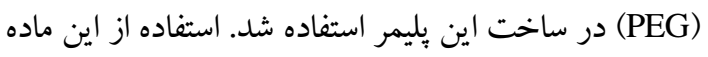
در يليمر يادشده تقريباً بيشتر مشكلات بيانشده را رفع كرد. لى و همكاران اثربخشى واكسنى زيرواحدى مر كب از

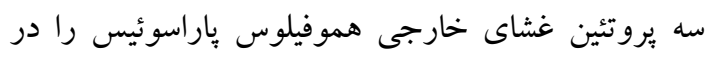

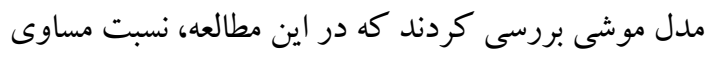

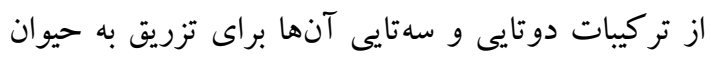

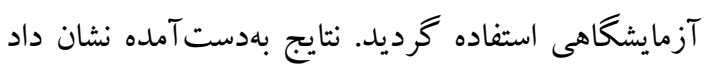

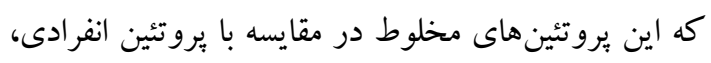
بيشترين ميزان آنتىبادى و ايمنىزايى را ايجاد مي كنئد (YF)

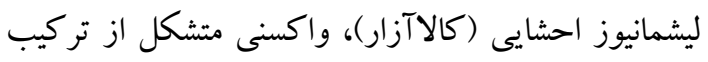

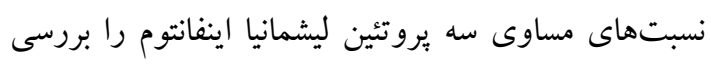

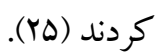
در يزوهش حاضر، در انتخاب نوع نانوذرهاى كه بتواند

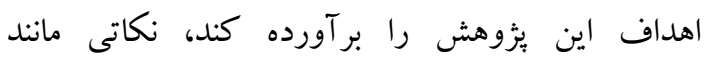
زيستساز كارى و زيست تخريب بذيرى، ساختار فيزيكى و شيميايى نانوذره، عدم آسيب به آنتىزن يعنى محلول در دري

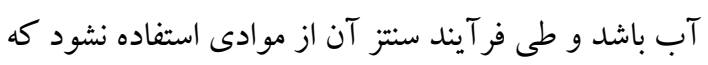

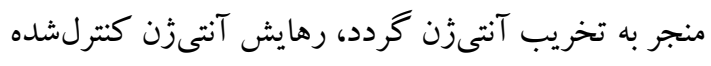
و قابل تنظيم، مقرونبهصرفه بودن تهيه و استفاده از آن آن

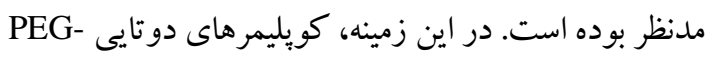

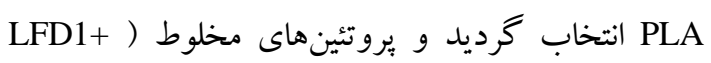
(PAD4
كويليمر PLA-PEG بهعنوان سامانههاى رسانش دارو و

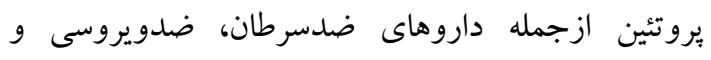
كانديداى واكسن براى بيمارىهاى مختلف استفادهشه درهاي

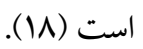

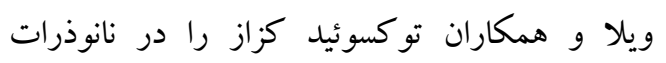
بليمرى دوبلوكة PLA-PEG بار گذارى كردند و بازده

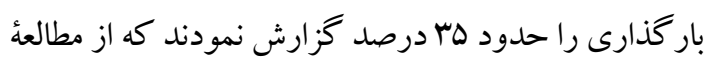
اين يزوهش كمتر است. در اين مطالعه، رهايش آنتىزن در

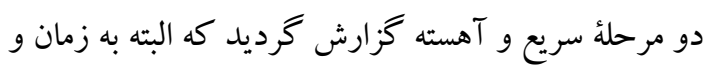
درصد آن اشارهاى نشده است (19).

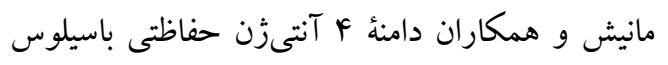

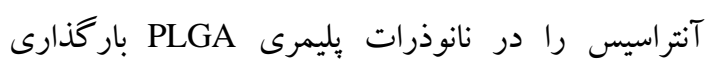

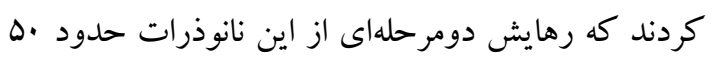

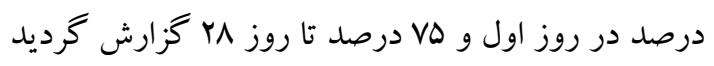

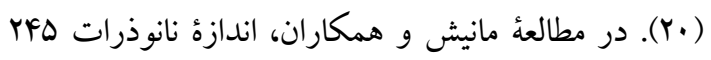

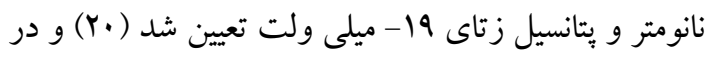

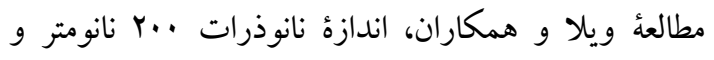
يتانسيل زتا حدود ه/ه در مطالعهُ ديخرى، قاسمى و همكاران فاكتور رشد مداند

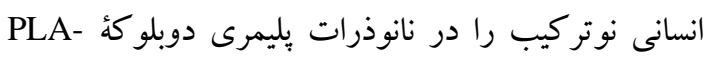

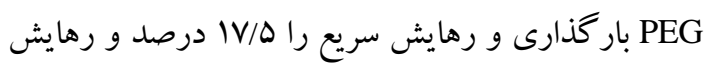

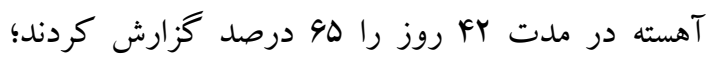

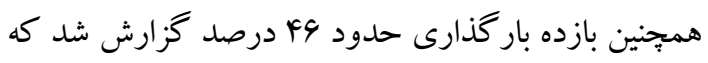

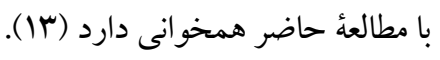

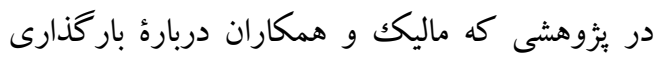
آنتىزن حفاظظى در نانوذرات كيتوزان انجام دادند، غلظت ماتِ مناسب كيتوزان براى بار گذارى حلدود · ا ميلى گرم و مقدار

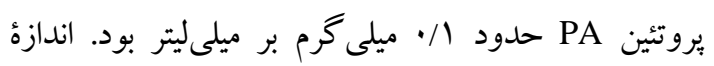

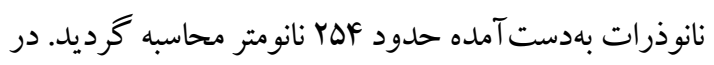
رهايش سريع، حلدود ·r درصد در زمان 9 ساعت و تا ...

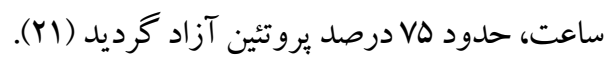

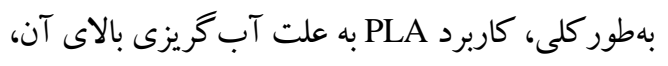

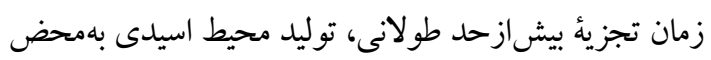

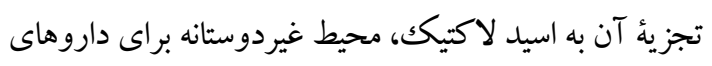




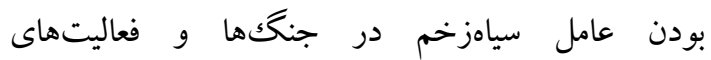
بيوتروريستى، طراحى سامانهاى براى ييشخيرى يا درمان يكك ضرورت است. در سالهاى اخير، تلاشهاى فراوانى براى استفاده از فناورى نانو بهمنظور تحويل دارو و واكسن

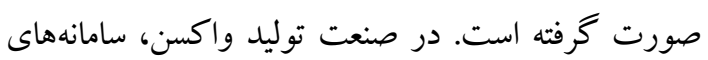
سنتى آنتىزنرسانى كه ميزان بارگيرى يايينى دارند، موجب تخريب بخشى از آنتىزن مىشوند. بايدارى اندكك، آزادسازى سريع آنتىزن را به دنبال دارد و انتقال مقدار موردنياز آنتىزن به بدن حيوان، نيازمند تكرار تزريق است؛ ستر بنابراين، با توجه به تخريب كمتر و حفاظت بيشتر فعاليت آنتىزن در نانوذرات نسبت به استفاده از روشهاى سنتى و نيز تكرار تزريق كمتر، اختصاصيت بالاتر، كاهش عوارض جانبى، هزينهُ كمتر و آهسته رهش بودن، استفاده از نانوذرات گزينهُ مناسبى براى جايخزين شدن با سامانهاى سنتى است.

\section{تعارض منافع \\ نويسندكان اعلام مى كنند كه تضاد منافعى در اين \\ مطالعه وجود ندارد.}

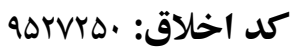

\section{References}

1. Riedel S, Hobden JA, Miller S, Morse SA, Mietzner TA, Detrick B, et al. Jawetz melnick adelbergs medical microbiology. 28th ed. Mcgraw Hill Publication. 2007; P.231-6.

2. Khardori N. Anthrax bacteriology clinical presentations and management in khardori bioterrorism preparedness medicine public health policy. Wiley VCH Verlag $\mathrm{GmbH}$ Weinheim Publication.2006; P. 123-45.

3. Gonzalez MR, Bischofberger M, Pernot L, Goot FG, Freche B. Bacterial poreforming toxins the hole story. Cell Mol Life Sci 2008; 65:493-507

4. Edwards KA, Clancy HA, Baeumner AJ. Bacillus anthracis toxicology, epidemiology and current rapid detection methods. Anal Bioanal Chem2006;384:73-84. doi.10.1007/s00216-0050090-x.

5. Gupta P, Waheed SM, Bhatnagar R. Expression and purification of the recombinant protective antigen of Bacillus anthracis. Prote Exp Pur 1999; 16:369-76. doi.10.1006/prep.1999.1066.

6. Wang, JY, Roehrl, MH. Anthrax vaccine design: strategies to achieve comprehensive protection against spore Bacillus and toxin. Med
شد كه رهايش آنتىزنهاى يادشده در دو مرحلة رهايش سريع و آهسته انجام مىشود كه آزادسازى يروتئينها در

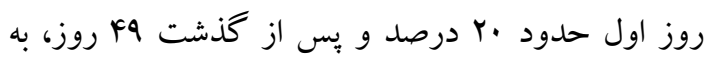
ميزان VA درصد محاسبه گرديد؛ همجنين بازده كيسولسازى آنتىزنها در اين نانوذرات حدود ها درصد تعيين شد. در اين مطالعه، بهترين شرايط براى باركذارى آنس يروتئين در نانوذرات PLA-PEG زمانى است كه محلول يليمر با غلظت ·r ميلى كرم در ليتر (r درصد) و ميزان يروتئين بارگذارىشده حدود r r ميلى گرم باشد. اندازء نانوذرات حاصل براى نانوذرات حاوى آنتىزن مخلوط حدود 9 ـ ا نانومتر بود.

مطابق با نتايج بهدست آمده، بررسى رهايش آنتىزن بلوسيلة كويليمرهاى دوتايى PLA-PEG نشان داد كه كويليمر بهدستآمده، بازدهى نسبتاً خوبى در حدود درصد دارد؛ همجنين سازو كار رهايش و پايدارى نانوذرات طولانى مدت است و با سرعت ثابتى آنتىزن را رها مى كند؛ درنتيجه به نظر مىرسد كه نانوذرات PLA-PEG يكك حامل كار آمد براى سامانههاى آنتىزنرسانى كنترلشده باشد. بنابراين، بر اساس مطالعات مختلف، بهترين راه

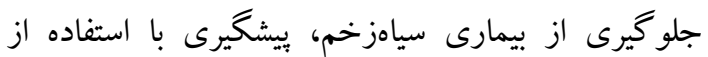
واكسنهاى مناسب است. به علت اهميت و قابلاستفاده

Immunol2005; 24: 4:4. doi.10.1186/1476-9433-4-4

7. Hepburn MJ, Hugh Dyson E, Simpson AJ, Brenneman KE, Bailey N, Wilkinson L, Hornby R, Mateczun AJ, Bell MG, Baillie LW. Immune response to two different dosing schedules of the anthrax vaccine precipitated vaccine. Vaccine2007; 25:6089-97. doi.10.1016/j.vaccine.2007.05.018.

8. Chi X, Li J, Liu W, Wang X, Yin K, Liu J, Zhang $X$. Generation and characterization of human monoclonal antibodies targeting anthrax protective antigen following vaccination with a recombinant protective antigen vaccine. Clin Vac Immunol 2015; 22: 553-60. doi.10.1128/CVI.00792-14

9. Williamson D, Dyson EH. Anthrax prophylaxis recent advances and future directions. Front Microbiol2015; 6, 1009. doi.10.3389/fmicb. 2015.01009

10. Knockenhauer KE, Sawicka KM, Roemer EJ, Simon SR. Protective antigen composite nanofibers as a transdermal anthrax vaccine. Con Proc IEEE Eng Med Biol Soc2008;5: 1040-3. doi. 10.1109/IEMBS.2008.4649337

11. Blum JS, Saltzman WM. High loading efficiency and tunable release of plasmid DNA encapsulated 
in submicron particles fabricated from Plga conjugated with poly $\mathrm{L}$ lysine]. J Cont Rel 2008;129:66-72. doi.10.1016/j.jconrel.2008.04.002

12. Ghasemi R, Abdollahi M, Zadeh EE, Khodabakhshi K, Badeli A, Bagheri $\mathrm{H}$, et al. Mpeg-pla and pla-peg-pla nanoparticles as new carriers for delivery of recombinant human growth hormone. Sci Rep2018;8:9854. doi.10.1038/ s41598-018-28092-8

13. Etemadaubi M, Honari H, Hajinourmohamadi A, Bagheri H, Noofeli M. [Assessment of cytotoxicity of Bacillus anthracis recombinant protective antigen in free and encapsulated forms by double block Pla-peg and Pcl-peg copolymers on vero cell]. Jundishapur Sci Med J 2018; 17:377-86. (Persian)

14. Singh NA, Mandal AKA, Khan ZA. Fabrication of Pla-peg nanoparticles as delivery systems for improved stability and controlled release of catechin. J Nanomate 2017; :1-9. doi. 10.1155/2017/6907149

15. Kim SK, Foote MB, Huang L. The targeted intracellular delivery of cytochrome $\mathrm{C}$ protein to tumors using lipid apolipoprotein nanoparticles]. Biomaterials2012;33:3959-66. doi. 10.1016/j. biomaterials.2012.02.010

16. Park J, Wrzesinski SH, Stern E, Look M, Criscione $\mathrm{J}$, Ragheb R, et al. Combination delivery of TGF $\beta$ inhibitor and IL2 by nanoscale liposomal polymeric gels enhances tumour immunotherapy. Nat Mate 2012;11:895-905. doi.10.1038/nmat3355

17. Manickavasagam D, Novak K, Oyewumi MO. Therapeutic delivery of simvastatin loaded in Plapeg polymersomes resulted in amplification of anti inflammatory effects in activated microglia. AAPS J2017;20:18. doi.10.1208/s12248-017-0176-3

18. Vila A, Gill H, Mccallion O, Alonso MJ. Transport of Pla-peg particles across the nasal mucosa effect of particle size and peg coating density]. J Cont Rel2004;98:231-44. doi.10.1016/j.jconrel.2004. 04.026

19. Manish M, Rahi A, Kaur M, Bhatnagar R, Singh S. A single dose Plga encapsulated protective antigen domain 4 nanoformulation protects Mice against Bacillus anthracis spore challenge. Plos One 2013;8:61885. doi.10.1371/journal.pone.0061885

20. Malik A, Gupta M, Mani R, Gogoi H, Bhatnagar R. Trimethyl chitosan nanoparticles encapsulated Protective antigen protects the Mice against anthrax. Front Immunol. 2018;9:562. doi. 10.3389/fimmu.2018.00562

21. Jain AK, Goyal AK, Mishra N, Vaidya B, Mangal S, Vyas SP. Peg-pla-peg block copolymeric nanoparticles for oral immunization against hepatitis B. Int J Pharm 2010;387:253-62. doi.10.1016/j.ijpharm.2009.12.013

22. Dong Y, Feng SS. Nanoparticles of poly D L-lactide methoxy poly ethylene glycol poly D L lactide blends for controlled release of paclitaxel. J Biomed Mate Res2006;78:9-12. doi. 10.1002/jbm.a.30684

23. Li M, Cai RJ, Song S, Jiang ZY, Li Y, Gou HC, Qiu HJ. Evaluation of immunogenicity and protective efficacy of recombinant outer membrane proteins of Haemophilus parasuis serovar 5 in a murine model. PLos One 2017;12:176537. doi.10.1371/journal.pone. 0176537

24. Martins VT, Chavezfumagalli MA, Lage DP, Duarte MC, Garde E, Costa LE. et al. Antigenicity immunogenicity and protective efficacy of three proteins expressed in the promastigote and amastigote stages of Leishmania infantum against visceral Leishmaniasis. PLos One2015;10:137683. doi. 10.1371/journal.pone.0137683 